\title{
Petrochemical features of the dike complex of the Vorontsovskoye gold-ore deposit (Northern Urals)
}

\author{
Oksana Borisovna AZOVSKOVA*, \\ Mikhail Yuryevich ROVNUSHKIN*, \\ Elena Industrovna SOROKA
}

Zavaritsky Institute of Geology and Geochemistry of the Ural Branch of RAS, Ekaterinburg, Russia

Relevance of the work. The Vorontsovskoye deposit has some peculiarities of the Carlin-type deposit and is one of the largest gold fields in the Urals. However, nowadays, it is almost worked out; similar objects in the region have not been identified. The dike complex of the stockwork type was not previously studied at the deposit. The undertaken research can help clarify both the model of formation of ore mineralization and the predictive model. Purpose of the work. Study of the composition and petrochemical features of the dike complex of the Vorontsovskoye deposit as one of the possible factors for the formation of gold-ore mineralization.

Methods of research. The measurements of the occurrence of dikes within the current open-pit with the results on the azimuth grid were carried out. A silicate dike sample assay was performed, and available past data was also used. The lithologic study of dikes was accompanied by the study of samples using the JSM-6390LV scanning electron microscope (JEOL) with the IncaEnergy-450 energy-dispersive spectrometer and the CamecaSX100 electron probe microanalyzer.

Results of the work. At the first stage of the research, the structural position of dikes was specified; results of lithologic and petrochemical studies and data obtained by microanalyzers were summarized. A significant prevalence of the main dikes with various compositions from picrobasalt to gabbrodiorite (andesibasalt) has been identified. A group of dikes with increased and high alkalinity (including lamprophyres) with compositions from moderately alkaline and alkaline picrobasalt to monzodiorite (trachyandesibasalt) has been identified as well. Occurrences of kalifeldspath metasomatism with the mineral association of chlorite-quartz- potassium feldspar-pyrite ( \pm galena) were recorded in dikes of complete line. Earlier, areas of kalifeldsparization were observed in tuff siltstones.

Conclusions. Availability of dike stockwork can be considered as a positive structural factor in the formation of the deposit. Its role as a magmatic factor is unclear; however, it can be assumed that occurrences of kalifeldsparization are allied to dykes of increased alkalinity.

Keywords: Northern Urals, Vorontsovskoye gold-ore deposit, dikes, petrochemistry, kalifeldspath metasomatism, Carlin-type.

\section{ntroduction}

The Vorontsovskoye deposit is located near Krasnoturyinsk in the north of the Sverdlovsk region. It is one of the most significant gold-ore sites in the Urals. Productive gold-sulphide mineralization has $\mathrm{Au}-\mathrm{As}-\mathrm{Hg}-\mathrm{Tl}-\mathrm{Sb}$ trend and can be associated with the "Carlin-type" for a number of characteristics $[1,2]$. At the same time, there are some signs of polygenic and polychronic formation of the deposit [1-4 et al.].

Regionally, the Vorontsovskoye deposit is located in the eastern part of the Tagil megazone within the Auerbah volcano-plutonic complex; it coincides with the Turinsko-Auerbahovskiy ore district of the Krasnoturyinsk ore zone. It is located $1.2 \mathrm{~km}$ west of the multi-phase Auerbah massif of gabbro-diorite-granite formation. Intrusions of the Auerbah complex, which form the massif and its associated intrusive bodies, date back to the early Devonian.

Gold mineralization is localized in the volcanogenic-sedimentary formations of the Krasnoturyinskaya suite ( $\mathrm{D}_{1} \mathrm{kr}$ ), which form the wing of a slightly pitching monoclinal structure within the volcano-tectonic depression (graben-synclinal fold). Ore-bearing formations are carbonate (brecciated limestone, carbonate breccia) and igneous-sedimentary (tuff siltstones, tuffaceous sandstones, tuffites) formations of the Lower Devonian. They are intruded with numerous dikes of basic and medium composition, which actually form a complex ore fold within the deposit (Fig. 1).

According to the geological works of various stages of the Auerbah ore cluster, to which the Vorontsovskoye deposit associated with, it is characterized by a large variety of dikes: dolerites and gabbro-dolerites, pyroxene-plagioclase, plagioclase and amphibole-plagioclase porphyrites, diorite- and quartzdiorite porphyry, lamprophyres of spessartite type, odonite, and kersantite. It should be noted that in most cases their determination is based only on petrographic research data. The dikes of the Vorontsovskoye deposit were slightly studied previously $[3,5]$, but the systemic work was not carried out. Their mineragenic type and a possible role in the formation of gold mineralization remains debated. This determines the relevance of the research, the first results of which are presented in this paper.

Objects and research methods, results of the work

During field works in 2017, more than 30 dikes were tested within the existing open-cut mining; structural measurements were carried out.

According to the results of measurements of dip azimuth (using historical measures), a graph was constructed (Fig. 2). It shows that there is a system discrete distribution of the poles in the Vorontsovskoye deposit. The systems of dikes of the north-northeast $\left(340^{\circ}-62^{\circ}\right)$, south-southeast $\left(90^{\circ}-190^{\circ}\right)$ and western $\left(235^{\circ}-292^{\circ}\right)$ dips are distinguished. Dip angles more than $60^{\circ}$ are characteristic for all systems. The first two systems with similar dip azimuth values are also noted in the work of I. V. Vikentyev [4].

oazovskova@yandex.ru

http://orcid.org/0000-0003-4251-7414

rovn@list.ru

D https://orcid.org/0000-0003-1759-2818

soroka@igg.uran.ru

D http://orcid.org/0000-0003-1360-6274 


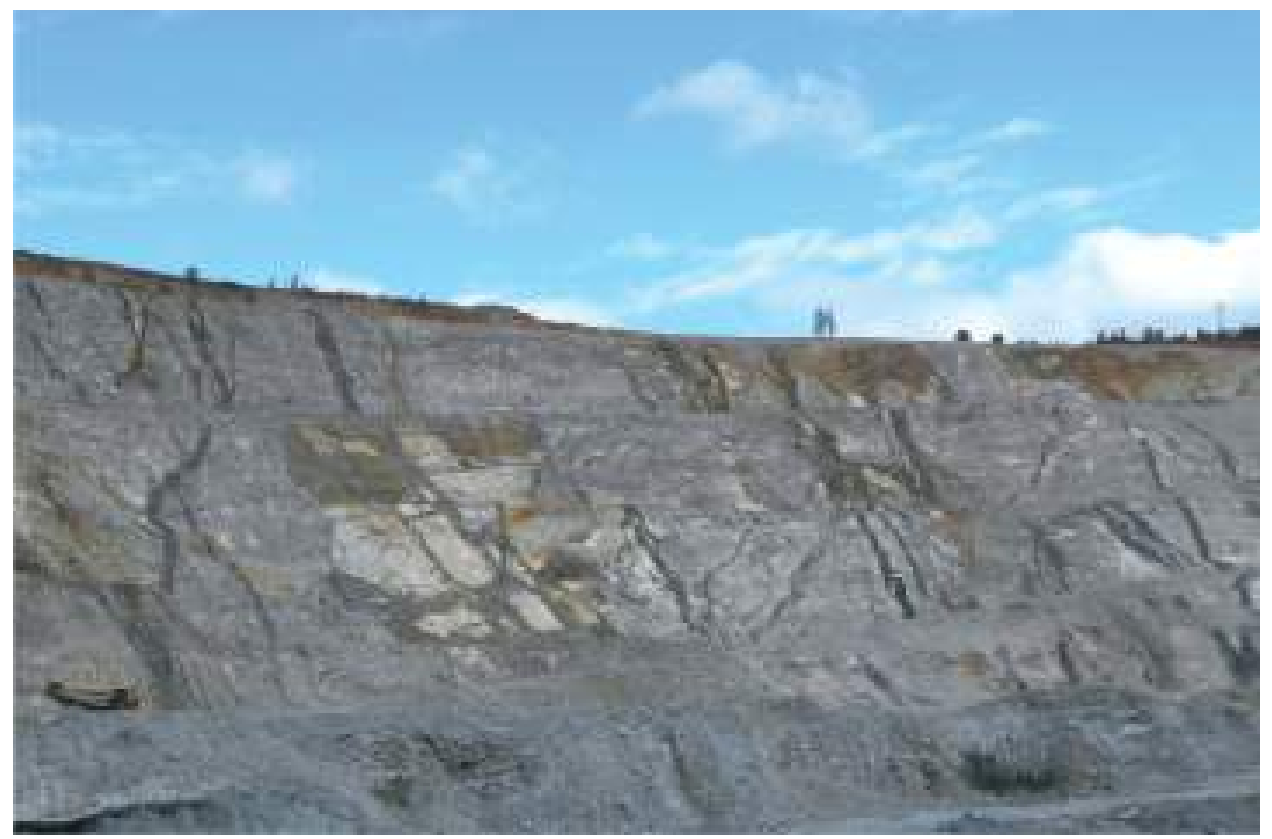

Figure 1. Plain view of the dike ore fold in the northern part of the Severny open-pit of the Vorontsovskoye deposit.

Рисунок 1. Общий вид дайкового штокверка в северной части Северного карьера Воронцовского месторождения.

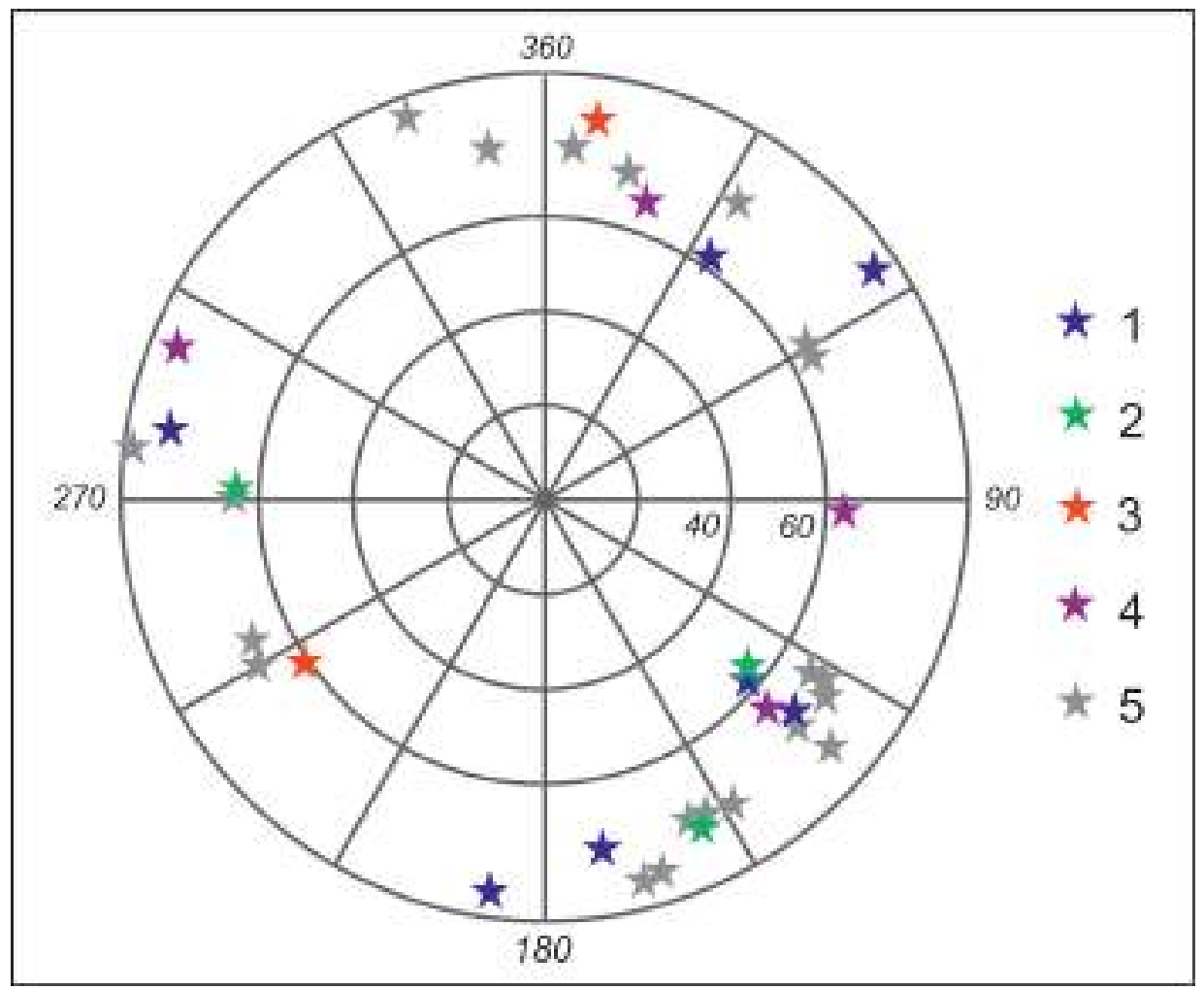

Figure 2. Graph of the dip and strike of dikes of the Vorontsovskoye deposit in the azimuth grid. 1 - dikes of basic composition (normal alkaline condition); 2 - dikes of medium composition (normal alkaline condition); 3 - dikes of increased alkaline condition; 4 - "neighboring composition" dikes (moderately alkaline / normal); 5 - no available data for chemical composition (according to TAS-diagram, Fig. 3).

Рисунок 2. Диаграмма распределения элементов залегания даек Воронцовского месторождения на азимутальной сетке. 1 дайки основного состава; 2 - дайки среднего состава; 3 - дайки повышенной щелочности; 4 - дайки «пограничного состава» (умереннощелочные/нормальные); 5 - нет данных по химическому составу. По TAS-диаграмме, рис. 2.

There are no obvious patterns in the distribution of dikes belonging to different groups by chemical composition, which may be due to a lack of data.

Data on the chemical composition of dikes are given in Table 1 (the analyses were performed in the laboratory of FHMI IGG of RAS, analyst is N. P. Gorbunov). Petrographic studies showed that all dikes were altered to some extent by the imposed metamorphic and metasomatic processes. The following Table 1 excludes full metasomatites, intensely sulfidized differences and analysis with values of the indicator "P.p.p." $\geq 7$. 
Table 1. The chemical composition of dikes of the Vorontsovskoye deposit.

Таблица 1. Химический состав даек Воронцовского месторождения.

\begin{tabular}{|c|c|c|c|c|c|c|c|c|c|c|}
\hline SI. No. & 1 & 2 & 3 & 4 & 5 & 6 & 7 & 8 & 9 & \\
\hline Sample, No. & $4 / 17$ & $6 / 17$ & $7 / 17$ & $10 / 17$ & $11 / 17$ & $14 / 17$ & $21-1 / 17$ & $21-2 / 17$ & $25 / 17$ & \\
\hline $\mathrm{SiO}_{2}$ & 50.31 & 46.88 & 50.84 & 54.53 & 49.63 & 53.60 & 50.74 & 51.50 & 49.45 & \\
\hline $\mathrm{TiO}_{2}$ & 0.74 & 0.75 & 0.99 & 0.64 & 0.61 & 0.66 & 0.54 & 0.64 & 0.67 & \\
\hline $\mathrm{Al}_{2} \mathrm{O}_{3}$ & 16.09 & 16.44 & 16.07 & 16.06 & 15.30 & 18.50 & 18.52 & 18.41 & 18.82 & \\
\hline $\mathrm{Fe}_{2} \mathrm{O}_{3}$ & 4.33 & 7.18 & 5.33 & 4.77 & 5.30 & 3.88 & 3.72 & 5.45 & 3.43 & \\
\hline $\mathrm{FeO}$ & 6.8 & 5.6 & 5.3 & 4.3 & 6.0 & 4.9 & 3.6 & 2.8 & 3.9 & \\
\hline $\mathrm{MnO}$ & 0.13 & 0.20 & 0.16 & 0.14 & 0.32 & 0.16 & 0.20 & 0.25 & 0.36 & \\
\hline $\mathrm{MgO}$ & 6.62 & 7.35 & 6.08 & 4.99 & 6.08 & 2.86 & 4.25 & 3.74 & 3.92 & \\
\hline $\mathrm{CaO}$ & 7.71 & 6.54 & 5.57 & 6.89 & 7.69 & 9.40 & 10.16 & 9.78 & 10.59 & \\
\hline $\mathrm{Na}_{2} \mathrm{O}$ & 2.25 & 2.95 & 3.11 & 2.47 & 2.76 & 2.72 & 3.05 & 3.87 & 2.87 & \\
\hline $\mathrm{K}_{2} \mathrm{O}$ & 0.91 & 0.82 & 0.55 & 1.94 & 0.90 & 1.53 & 1.37 & 1.25 & 2.24 & \\
\hline $\mathrm{P}_{2} \mathrm{O}_{5}$ & 0.24 & 0.15 & 0.12 & 0.21 & 0.15 & 0.16 & 0.19 & 0.21 & 0.26 & \\
\hline V & 0.026 & 0.032 & 0.023 & 0.020 & 0.024 & 0.020 & 0.014 & 0.016 & 0.020 & \\
\hline $\mathrm{Cr}$ & 0.008 & 0.005 & 0.005 & 0.010 & 0.006 & 0.012 & 0.003 & 0.009 & 0.007 & \\
\hline $\begin{array}{l}\text { Percentage of other } \\
\text { impurities }\end{array}$ & 3.6 & 4.8 & 5.6 & 2.8 & 5.0 & 1.3 & 3.4 & 2.1 & 3.2 & \\
\hline Amount & 99.75 & 99.70 & 99.74 & 99.76 & 99.76 & 99.69 & 99.75 & 100.02 & 99.73 & \\
\hline S & 2.10 & 1.80 & $\mathrm{n} / \mathrm{a}$ & $\mathrm{n} / \mathrm{a}$ & 0.02 & 0.07 & 1.08 & 0.46 & 0.34 & \\
\hline SI. No. & 10 & 11 & 12 & 13 & 14 & 15 & 16 & 17 & 18 & 19 \\
\hline Sample, No. & $26 / 17$ & $26-1 / 17$ & $28 / 17$ & $29-2 / 17$ & $29-3 / 17$ & $30 / 17$ & $31 / 17$ & $34-1 / 17$ & $34-2 / 17$ & $35 / 17$ \\
\hline $\mathrm{SiO}_{2}$ & 42.71 & 41.50 & 52.69 & 45.15 & 51.09 & 49.48 & 47.51 & 54.54 & 50.80 & 50.64 \\
\hline $\mathrm{TiO}_{2}$ & 0.68 & 0.60 & 0.58 & 0.57 & 0.64 & 0.72 & 0.91 & 0.59 & 0.84 & 0.45 \\
\hline $\mathrm{Al}_{2} \mathrm{O}_{3}$ & 21.47 & 19.48 & 16.29 & 15.57 & 18.82 & 15.02 & 15.31 & 15.12 & 15.85 & 18.19 \\
\hline $\mathrm{Fe}_{2} \mathrm{O}_{3}$ & 3.60 & 8.05 & 3.76 & 5.76 & 6.07 & 7.03 & 6.31 & 4.19 & 6.06 & 6.51 \\
\hline $\mathrm{FeO}$ & 1.8 & 1.4 & 5.7 & 4.6 & 4.2 & 1.4 & 3.9 & 5.3 & 1.0 & 3.1 \\
\hline $\mathrm{MnO}$ & 1.06 & 0.63 & 0.14 & 0.19 & 0.15 & 0.12 & 0.17 & 0.15 & 0.09 & 0.17 \\
\hline $\mathrm{MgO}$ & 4.82 & 3.57 & 6.32 & 10.78 & 3.42 & 9.22 & 4.48 & 4.40 & 7.43 & 3.38 \\
\hline $\mathrm{CaO}$ & 16.81 & 16.53 & 7.88 & 9.63 & 8.09 & 9.44 & 11.43 & 7.71 & 7.75 & 9.69 \\
\hline $\mathrm{Na}_{2} \mathrm{O}$ & 1.12 & 1.68 & 2.28 & 1.80 & 3.25 & 2.52 & 2.95 & 3.03 & 2.58 & 2.30 \\
\hline $\mathrm{K}_{2} \mathrm{O}$ & 2.06 & 0.77 & 1.34 & 0.39 & 0.98 & 0.16 & 0.67 & 0.99 & 2.29 & 0.80 \\
\hline $\mathrm{P}_{2} \mathrm{O}_{5}$ & 0.24 & 0.22 & 0.13 & 0.06 & 0.25 & 0.16 & 0.14 & 0.18 & 0.40 & 0.16 \\
\hline V & 0.017 & 0.014 & 0.021 & 0.022 & 0.019 & 0.014 & 0.020 & 0.021 & 0.016 & 0.011 \\
\hline $\mathrm{Cr}$ & 0.006 & 0.005 & 0.008 & 0.042 & 0.006 & 0.039 & 0.007 & 0.010 & 0.016 & 0.005 \\
\hline $\begin{array}{l}\text { Percentage of other } \\
\text { impurities }\end{array}$ & 3.6 & 5.5 & 2.5 & 5.3 & 2.7 & 4.7 & 6.1 & 3.3 & 4.9 & 4.4 \\
\hline Amount & 99.98 & 99.96 & 99.61 & 99.85 & 99.67 & 100.03 & 99.95 & 99.53 & 100.03 & 99.82 \\
\hline$S$ & 0.83 & 4.54 & $\mathrm{~N} / \mathrm{a}$ & $\mathrm{N} / \mathrm{a}$ & $\mathrm{N} / \mathrm{a}$ & $\mathrm{N} / \mathrm{a}$ & $\mathrm{N} / \mathrm{a}$ & 0.05 & $\mathrm{~N} / \mathrm{a}$ & $\mathrm{N} / \mathrm{a}$ \\
\hline SI. No. & 20 & 21 & 22 & 23 & 24 & 25 & 26 & 27 & 28 & 29 \\
\hline Sample, No. & $36 / 17$ & 905 & 909 & 913 & 926 & 933 & 934 & 1590 & $2[5]$ & 3 [5] \\
\hline $\mathrm{SiO}_{2}$ & 46.65 & 45.95 & 48.05 & 53.87 & 41.0 & 46.04 & 49.2 & 52.55 & 49.69 & 52.24 \\
\hline $\mathrm{TiO}_{2}$ & 0.70 & 0.77 & 0.58 & 0.65 & 0.75 & 0.72 & 0.56 & 1.19 & 0.52 & 0.83 \\
\hline $\mathrm{Al}_{2} \mathrm{O}_{3}$ & 16.99 & 17.58 & 15.47 & 18.55 & 20.47 & 12.54 & 14.49 & 12.08 & 17.88 & 18.67 \\
\hline $\mathrm{Fe}_{2} \mathrm{O}_{3}$ & 8.77 & 5.81 & 3.06 & 1.96 & 2.15 & 6.13 & 3.92 & 3.44 & 3.3 & 2.31 \\
\hline $\mathrm{FeO}$ & 5.2 & 5.0 & 8.55 & 4.6 & 6.6 & 4.3 & 5.2 & 2.8 & 5.34 & 5.73 \\
\hline $\mathrm{MnO}$ & 0.20 & 0.13 & 0.14 & 0.22 & 0.44 & 0.16 & 0.13 & 0.12 & 0.19 & 0.20 \\
\hline $\mathrm{MgO}$ & 6.87 & 2.85 & 5.69 & 3.15 & 4.72 & 13.02 & 6.3 & 8.34 & 7.22 & 4.22 \\
\hline $\mathrm{CaO}$ & 9.22 & 7.1 & 7.39 & 9.52 & 9.48 & 8.17 & 8.22 & 6.7 & 9.55 & 9.75 \\
\hline $\mathrm{Na}_{2} \mathrm{O}$ & 2.11 & 3.55 & 3.2 & 2.95 & 2.45 & 2.1 & 2.55 & 2.4 & 2.42 & 2.62 \\
\hline $\mathrm{K}_{2} \mathrm{O}$ & 0.68 & 1.59 & 1.57 & 2.2 & 3.12 & 0.66 & 1.52 & 5.0 & 0.98 & 0.96 \\
\hline $\mathrm{P}_{2} \mathrm{O} 5$ & 0.10 & 0.24 & 0.15 & 0.18 & 0.22 & 0.15 & 0.15 & 0.84 & 0.10 & 0.15 \\
\hline$v^{2}$ & 0.036 & - & - & - & - & - & - & - & - & - \\
\hline $\mathrm{Cr}$ & 0.008 & - & - & - & - & - & - & - & - & - \\
\hline $\begin{array}{l}\text { Percentage of other } \\
\text { impurities }\end{array}$ & 2.2 & 6.6 & 4.2 & 1.6 & 6.4 & 5.8 & 5.0 & 4.3 & - & 1.9 \\
\hline Amount & 99.98 & 97.19 & 98.00 & 99.49 & 97.75 & 99.75 & 97.21 & 99.78 & 97.19 & 99.55 \\
\hline$S$ & 0.03 & 0.04 & 1.4 & 0.16 & 2.2 & 0.22 & 2.37 & 0.16 & trace & $\mathrm{N} / \mathrm{a}$ \\
\hline
\end{tabular}

Note: No. 1-20 samples of 2017, No. 21-27 samples of 2009. 
In the classification TAS-diagram (Fig. 3), the dikes of the Vorontsovskoye deposit fall mainly in the area of the main rocks, and only some of them - in the area of the middle rocks. It is noteworthy that there are not only quartz diorites among the dikes but also diorites typical of the area as a whole. In addition, the presence of two trends - normal alkalinity condition and hyperalkalinity - is clearly visible, and in the latter, there are dikes corresponding in composition to ultrabasic formations - picrobasalts.

According to the petrographic characteristics, several main types of dikes are distinguished (the corresponding numbers are given in parentheses for Table 1):

1. Porphyric pyroxene-plagioclase dikes (from essentially pyroxene to essentially plagioclase ones) of basalt, less often andesibasalt composition (Nos. 1, 2, 3, 5, 7, 8, 13, 19, 20).

2. Dolerites, incl. porphyritic ones (Nos. 4,28 ).

3. Porphyritic amphibole-plagioclase dikes ( \pm pyroxene) of predominantly andesitic composition $(6,16,23,29)$.

4. Gabbro, gabbro-dolerity, incl. alkalized (Nos. 9, 14, 15).

5. Gabbrodiorite-diorite (Nos. 12, 26).

6. Lamprophyre of spessartite type (Nos. 18, 25) and kersantite (No. 27).

It should be noted that moderate alkaline and alkalized differences (with the exception of lamprophyres and relatively coarsegrained gabbroids) are quite difficult to identify in conventional petrographic studies; and the presence of potassium feldspar is mainly determined by using more detailed physical methods of research - a scanning electron microscope (SEM). Micrographs of individual species of dikes are shown in Fig. 4, 5.

The relationship of dikes of different composition within the field is still unclear, although there are separate observations, for example, a distinct intersection (pyroxene) -plagioclase porphyry dikes of the average composition of the dike of corniferous lamprophyre of the spessartite type (Fig. 5).

According to the results of studies of polished thin sections carried out using the JSM-6390LV scanning electron microscope (JEOL) with the IncaEnergy-450 energy-dispersive spectrometer and the CamecaSX100 electron probe microanalyzer, the composition was specified of disseminated minerals in the most common porphyritic dikes - pyroxene-plagioclase of basic composition and amphibole-plagioclase of medium composition (studies were conducted on previously selected samples). It is determined that plagioclase of disseminated minerals in dikes of both types is represented by labradorite with small differences in the content of the anorthite minal. The compositions of pyroxene correspond to augite, and amphibole - hornblende (Table 2).

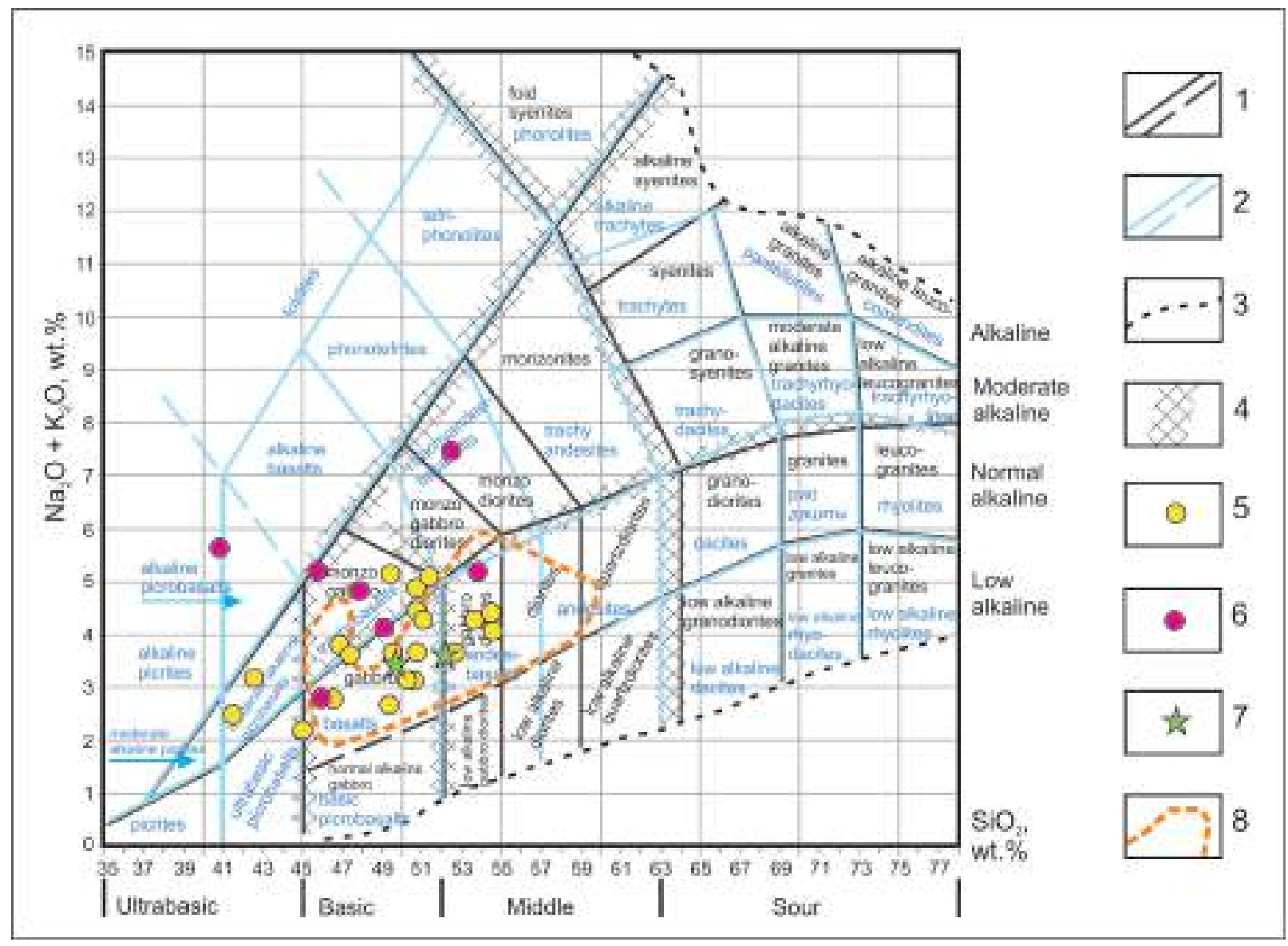

Figure 3. The position of the dikes of the Vorontsovskoye deposit in the TAS-diagram. 1 -intrusive rocks; 2 -igneous rocks; 3 - boundaries of the distribution of plutonic rock; 4 - ambiguity areas; 5 - samples of 2017; 6 - samples of 2009 according to [5]; 7 - reported by V. N. Sazonov et al. [3]; 8 - composition of dikes in the Vorontsovskoye deposit (according to geological prospecting data; Ufimtsev, 1968).

Рисунок 3. Положение даек Воронцовского месторождения на TAS-диаграмме. 1 - интрузивные породы; 2 - вулканогенные породы; 3 - границы распространения магматических пород; 4 - зоны неопределенности; 5 - пробы 2017 г.; 6 - пробы 2009 г. по [5]; 7 - по В. Н. Сазонову и др. [4]; 8 - составы даек в районе Воронцовского месторождения (по данным геолого-поисковых работ; Уфимцев, 1968). 

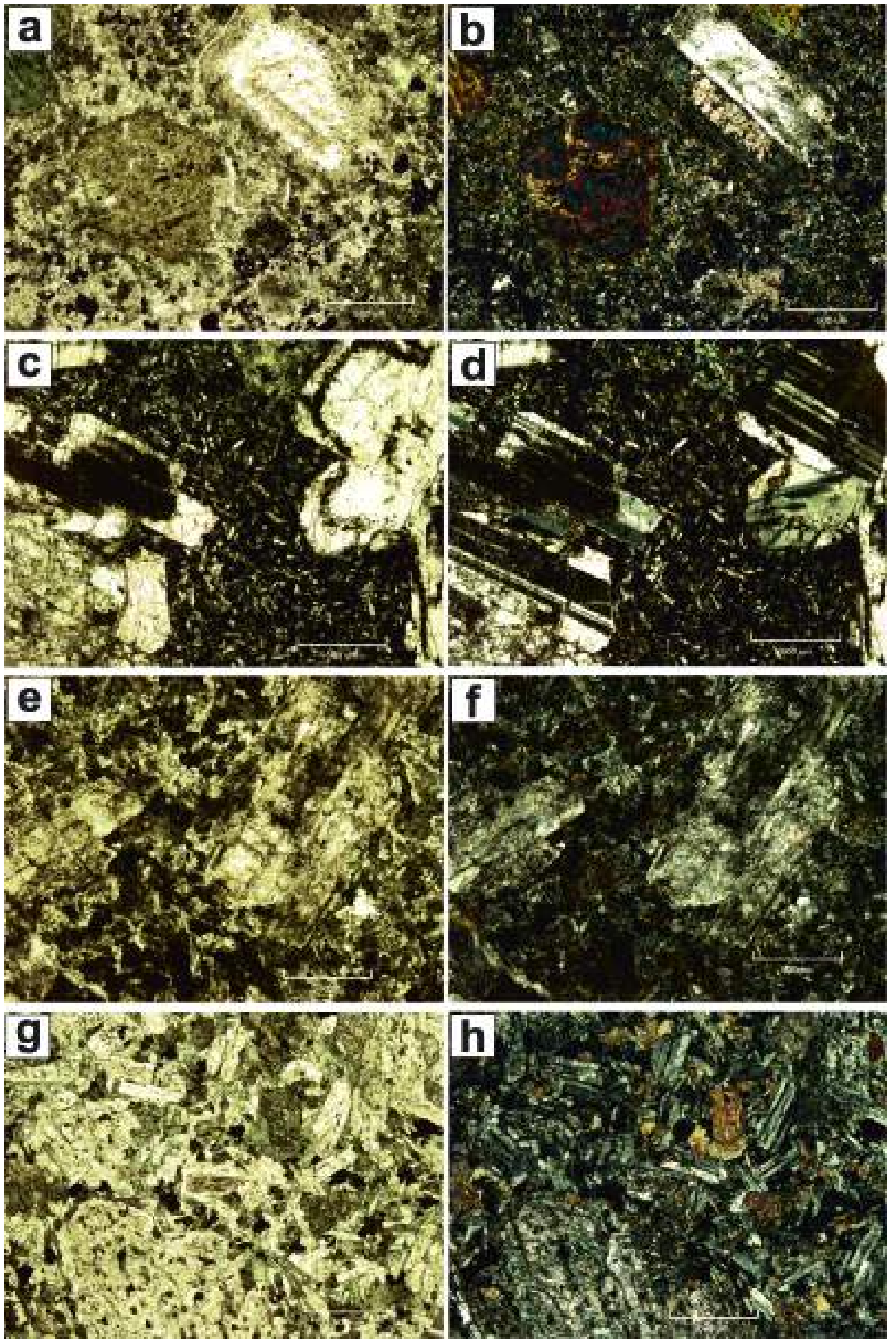

Figure 4. Photos of thin sections of individual types of dikes of the Vorontsovskoye deposit (on the left hand side - without an analyzer, on the right-hand side - in crossed Nicol). Ruler - 500 microns. a, b - Px-PI-porphyry dike of basic composition, sample 4/17 (No. 1); c, d (Px)-PI-porphyry dike of andesite-andesite-basalt composition, sample 6/17 (No. 2); e, f-porphyric gabbro-monzogabbro, sample 25/17 (No 9); g, h - porphyric gabbro-diorite, sample 28/17 (No. 12).

Рисунок 4. Фотографии шлифов отдельных типов даек Воронцовского месторождения (слева - без анализатора, справа - в скрещенных николях). a, b - Px-PI-порфировая дайка основного состава, обр. 4/17 (№ 1); c, d - (Px)-PІ-порфировая дайка андезитандезибазальтового состава, обр. 6/17 (№ 2); e, f - габбро-монцогаббро порфировидное, обр. 25/17 (№ 9); g, h - габбро-диорит порфировидный, обр. 28/17 (№ 12). 
Table 2. The chemical composition of disseminated minerals in the main dikes of the Vorontsovskoye deposit according to microprobe studies. Таблица 2. Химический состав вкрапленников в основных дайках Воронцовского месторождения по данным микрозондовых исследований.

\begin{tabular}{|c|c|c|c|c|c|c|c|c|c|c|}
\hline $\mathrm{SiO}_{2}$ & $\mathrm{TiO}_{2}$ & $\mathrm{Al}_{2} \mathrm{O}_{3}$ & $\mathrm{FeO}$ & $\mathrm{MnO}$ & $\mathrm{MgO}$ & $\mathrm{CaO}$ & $\mathrm{Na}_{2} \mathrm{O}$ & $\mathrm{K}_{2} \mathrm{O}$ & $\mathrm{N}$ & Sample \\
\hline \multicolumn{11}{|c|}{ Plagioclase } \\
\hline 51.22 & 0.03 & 29.29 & 0.92 & 0.01 & 0.13 & 13.57 & 3.9 & 0.36 & 4 & Bop-91-5a \\
\hline 51.68 & 0.04 & 29.11 & 0.82 & 0.01 & 0.11 & 13.22 & 4.10 & 0.34 & 5 & Вор-91-5б \\
\hline 52.35 & 0.04 & 29.25 & 0.76 & 0.01 & 0.14 & 11.88 & 4.13 & 0.77 & 7 & Bop-103-2 \\
\hline \multicolumn{11}{|c|}{ Clinopyroxene } \\
\hline 50.68 & 0.39 & 2.98 & 8.13 & 0.43 & 12.92 & 24.16 & 0.20 & 0.00 & 5 & Bop-91-5 \\
\hline 47.43 & 0.70 & 6.60 & 7.30 & 0.13 & 13.18 & 23.73 & 0.22 & 0.00 & 4 & Bop-91-5 \\
\hline \multicolumn{11}{|c|}{ Amphibole } \\
\hline $48.5-52.99$ & $0.02-0.34$ & $1.59-5.23$ & $14.84-17.2$ & $0.6-0.82$ & $12.23-14.08$ & $10.9-12.69$ & $0.16-0.57$ & $0.04-0.2$ & 7 & Bop-103-2 \\
\hline
\end{tabular}

Note: $\mathrm{N}$ is the number of identifications; values are italicized $<2 \sigma$. CamecaMX 100 microprobe analyzer, the Zavaritsky Institute of Geology and Geochemistry of the Ural Branch of the Russian Academy of Sciences, the analyst is D. S. Zamyatin).
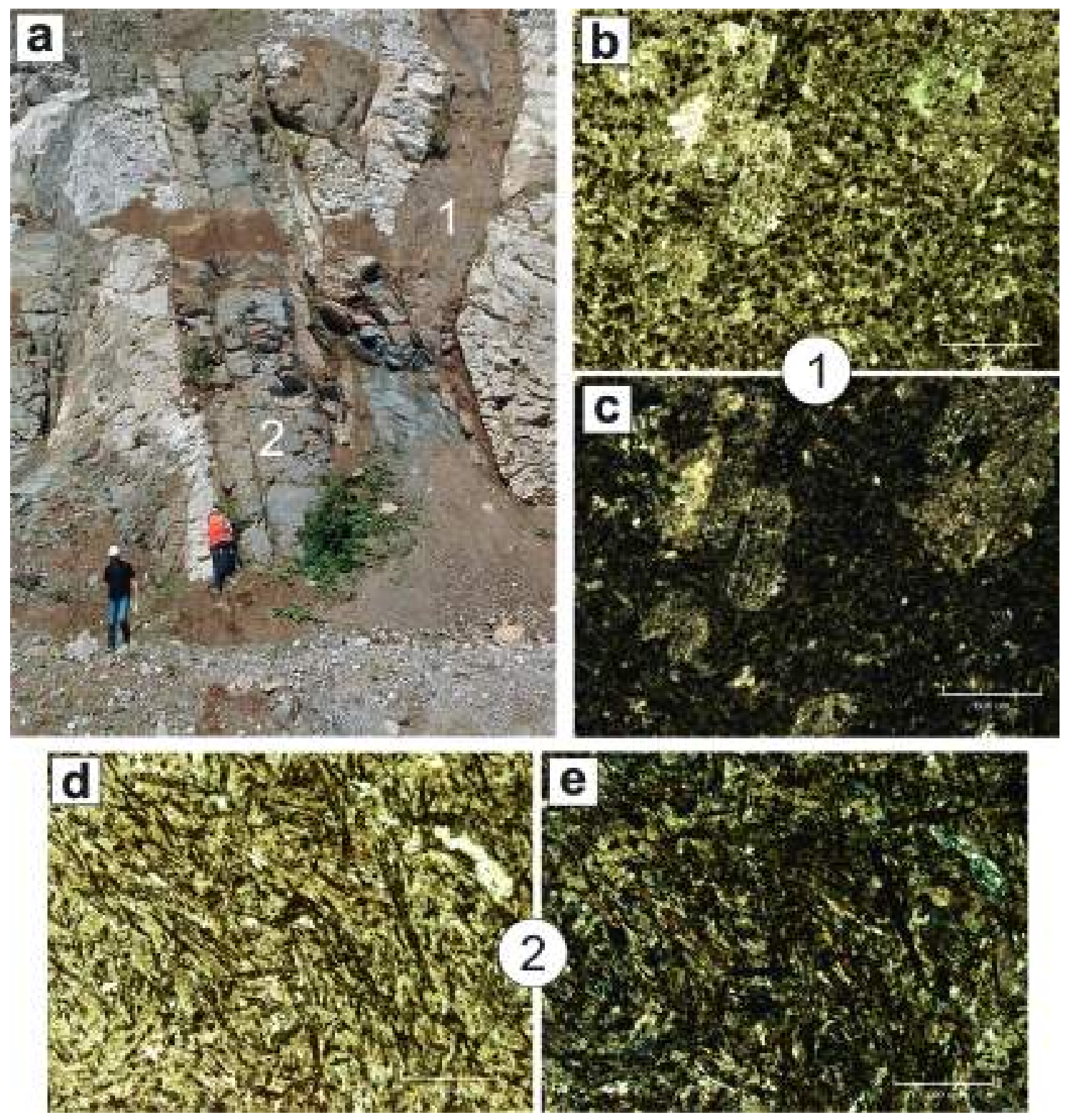

Figure 5. An example of the relationship of dikes of different composition. a - suppression of (Px)-PI-porphyritic dyke of andesite-andesibasalt composition (1) with a dike of spessartite (2); bc - general view in thin section (Px)-PI-porphyry dike, without analyzer (b) and in crossed nicol (c), sample 34-4-1/17 (No. 17); d, e - general view in thin section of spessartite dikes, without analyzer (d) and in crossed nicol (e), sample 34-2/17 (No. 18).

Рисунок 5. Пример взаимоотношения даек различного состава. а-пресечение (Px)-PI-порфировой дайки андезит-андезибазальтового состава (1) дайкой спессартита (2); b, c - общий вид в шлифе (Px)-PI-порфировой дайки без анализатора (b) и в скрещенных николях (c), обр. 34-1/17 (№ 17); d, е - общий вид в шлифе дайки спессартита без анализатора (d) и в скрещенных николях (e), обр. 34-2/17 (№ 18). 

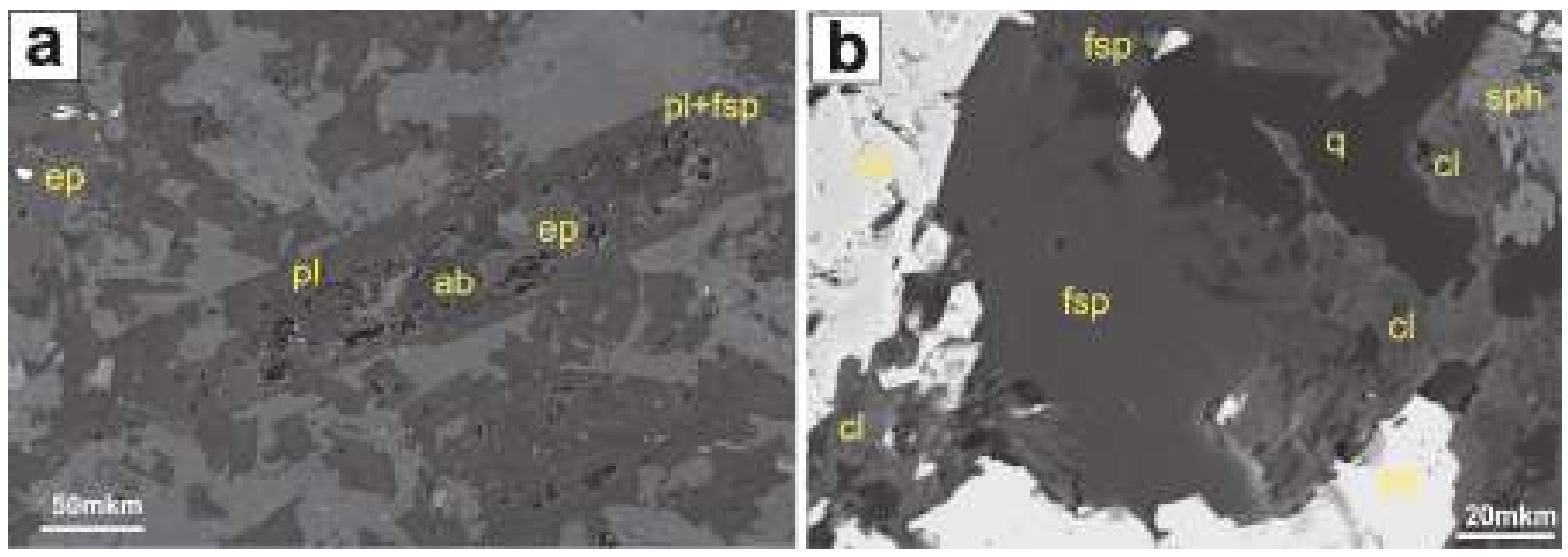

Figure 6. Peculiarities of potassium feldspar (fsp) release in the initial rock of normal alkalinity (a) and in the area of quartz-kalifeldspar metasomatism (b); sample 4/17. ab - albite, cl - chlorite, ep - epidote, pl - plagioclase, py - pyrite, q - quartz, sph - sphene.

Рисунок 6. Особенности выделений КПШ (fsp) в исходной породе нормальной щелочности (а) и на участке кварц-калишпатового метасоматоза (b); обр. 4/17. ab - альбит, cl - хлорит, ер - эпидот, pl - плагиоклаз, ру - пирит, q - кварц, sph - cфен.

In addition, in the detailed studies of polished thin sections in dikes similar in composition (samples 4/17, 6/17), occurrences of quartz-kalifeldspath metasomatism were found. They are small plots and irregularly shaped patches composed by the chlorite-quartz-potassium feldspar-pyrite association (Fig. 6, b). Titanite (sphene) usually occurs, and galenite is sometimes intruded in pyrite. Potassium feldspar is characterized by the admixture of a small amount of barium (Ba, $0.32-0.53 \% \mathrm{w}$.). In the same thin sections, potassium and sodium-potassium feldspar were observed in the form of uneven discontinuous margins (with intimate intergrowth) at the edges of disseminated plagioclase (Fig. 6, a) and, in some cases, in the form of patches (antiperthites?) in the inner parts of large disseminated minerals. It can be assumed that this potassium feldspar is "petrean" or that associated with some previous process of kalifeldsparization.

In the process of exploratory development in 2009-2010, occurrences of intense kalifeldsparization in tuff siltstones were identified at the Vorontsovskoye deposit within one of the ore blocks opened by the existing open-cut mining [6]. Optically, these kalifeldsparized sites did not stand out and were detected by abnormally high potassium levels (up to 7-10\% of weight according to ICP-MS). Potassium feldspar in metasomatites is represented by a fine-grained aggregate $(20-50 \mu \mathrm{m}$, rarely up to $200 \mu \mathrm{m})$ in association with quartz. According to the results of microprobe determinations and X-ray diffraction analysis of rocks, it can be assumed that these are orthoclase and/or sanidine. It should also be noted that earlier V. N. Sazonov with his coauthors [3] identified propylitized rocks in the area of the deposit with ice spar replacing plagioclase.

Discussion of results and conclusions

The importance of dikes in the formation of the Vorontsovskoye gold-ore deposit remains debated. Typically, the "dense" dike ore fold is observed only within the deposit, which confirms the important role of dikes as a factor of structural control [4]. The dike complexes of most Carlin-type deposits of the state of Nevada (USA) [4, 7, 8-10] and separate objects within the territory of the PRC [11-13] have the same importance.

The role of dikes as a magmatic factor is more difficult. In the eastern part of Nevada, where a large number of deposits of this type are found, four cases of magmatic activity are noted; one of them (magmatism of the Eocene period) is considered to be important in the formation of ore mineralization $[4,7,10]$. As for the Vorontsovskoye deposit is concerned, most researchers assume some kind of connection of gold mineralization with magmatic and post-magmatic processes, but there is no certainty in this matter. In this regard, an important result is the identification of occurrences of kalifeldspath (quartz-kalifeldspath) metasomatism, which is presumably associated with dikes of increased alkalinity and may play a role in the formation of gold-ore mineralization. These dikes are most likely referred to the Auerbah complex, the 2nd and 3rd phases of which have a sub-alkaline and high-potassium specialization (The tale of the Urals series..., A. V. Zhdanov, 2009). At the same time, occurrences of kalifeldspath metasomatism may lend credence to assumptions of O. V. Minina [14], A. I. Grabezhev [15] and some other researchers concerning the possible belonging of gold-ore mineralization to the upper and/or peripheral parts of a large porphyry system.

Acknowledgements

This work was performed within the framework of the state order of the Zavaritsky Institute of Geology and Geochemistry of the Ural Branch of the Russian Academy of Sciences (State registration No AAAA-A18-118052590030-2).

\section{REFERENCES}

1. Sazonov V. N., Murzin V. V., Grigoriev N. A. 1998, Vorontsovskoe gold deposit - an example of mineralization of the Carlin type in the Urals. Geologiya rudnykh mestorozhdeniy [Geology of Ore Deposits], vol. 40, no. 2, pp. 157-170. (In Russ.)

2. Murzin V. V., Naumov E. A., Azovskova O. B., Varlamov D. A., Rovnushkin M. Yu., Pirajno F. 2017, The Vorontsovskoe Au-Hg-As ore deposit (Northern Urals, Russia): Geological setting, ore mineralogy, geochemistry, geochronology and genetic model. Ore Geology Reviews, vol. 85, pp. 271-298. https://dx.doi.org/10.1016/j.oregeorev.2016.10.037

3. Vikentyev I. V., Tyukova E. E., Murzin V. V. et al. 2016, Vorontsovskoye zolotorudnoye mestorozhdeniye. Geologiya, formy zolota, genezis [The Vorontsovskoe gold ore deposit. Geology, forms of gold, genesis]. Ekaterinburg, $206 \mathrm{p}$.

4. Sazonov V. N., Murzin V. V., Grigoriev N. A., Gladkovsky B. A. 1991, Endogennoye orudeneniye devonskogo andezitoidnogo vulkano-plutonicheskogo kompleksa (Ural) [Endogenetic ore mineralization of the Devonian andesitoid volcano-plutonic complex (Ural)]. Sverdlovsk, $184 \mathrm{p}$.

5. Nechkin G. S., Rovnushkin M. Yu. 2011, Sulfide dike mineralization at the Vorontsovskoye gold deposit (Auerbah complex, Northern Urals), Ezhegodnik-2010 [Yearbook-2010], vol. 158, pp. 187-190. (In Russ.) 
6. Rovnushkin M. Yu., Gulyaeva, T. Ya., Galakhova O. L. 2010, Occurrence of kalifeldspath metasomatism within the Vorontsovskoye gold-ore deposit. Ezhegodnik-2010 [Yearbook-2010], vol.157, pp. 241-244. (In Russ.)

7. Cline J. S., Hofstra F. F. 2000, Ore-fluid evolution at the Getchell Carlin-type gold deposit, Nevada, USA. European Journal of Mineralogy, vol.12, no. 1, pp. 195-212. https://dx.doi.org/10.1127/ejm/12/1/0195

8. Cline J. S., Hofstra F. F., Muntean J. L. et al. 2005, Carlin-type gold deposits in Nevada: critical geologic characteristics and viable models. Economic Geology. 100th Anniversary volume, pp. 451-484. URL: https://pyrite.utah.edu/fieldtrips/SEGFnevada2007/Readings/General_CTD/ Cline2005.pdf

9. Ressel M. W., Henry C. D. 2006, Igneous geology of the Carlin Trend, Nevada: development of the eocene plutonic complex and significance for Carlin-type gold deposits. Economic Geology, vol.101, no. 2, pp. 347-383. https://doi.org/10.2113/econgeo.105.5.971

10. Almeida C. M., Olivo G. R., Chouinard A., Weakly Ch., Poirier G. 2010, Mineral Paragenesis, alteration, and geochemistry of the two types of gold ore and the host rocks from the Carlin-type deposits in the southern part of the Goldstrike Property, Northern Nevada: implications for sources of ore-forming elements, ore genesis, and mineral exploration. Economic Geology, vol.105, pp. 971-1004.

11. Liu J., Dai H., Zhai D., Wang J., Wang Y, Yang L., Mao G. et al. 2015, Geological and geochemical characteristics and formation mechanism of the Zhaishang Carlin-like type gold deposit, western Qinling Mountains, China. Ore Geology Reviews, vol. 64. https://doi.org/10.1016/j.oregeorev.2014.07.016

12. Wang L., Zhu Y. 2015, Multi-stage pyrite and hydrothermal mineral assemblage of the Hatugold district (west Junggar, Xinjiang, NW China): Implications formetallogenic evolution. Ore Geology Reviews, vol. 69, pp. 243-267. https://dx.doi.org/10.1016/j.oregeorev.2015.02.021

13. Zhu J.-J., Hu R.-Zh., Richards J. P., Bi X.-W., Stern R., Lu G. 2017, No genetic link between Late Cretaceous felsic dikes and Carlin-type Au deposits in the Youjiang basin, Southwest China. Ore Geology Reviews, vol. 84, pp. 328-337. https://dx.doi.org/10.1016/j.oregeorev.2017.01.014 14. Minina O. V. 1994, Auerbah complex ore-magmatic system in the Middle Urals. Otechestvennaya geologiya [Russian Geology], No. 7, pp. 17-23. (In Russ.)

15. Grabezhev A. I., Ronkin Yu. L., Puchkov V. N., Gerdes A., Rovnushkin M. Yu. 2014, Krasnoturyinsk copper-scarn ore field (Northern Urals): $\mathrm{U}-\mathrm{Pb}$ age of ore-controlling diorites and their place in the metallogeny of the region. Doklady Akademii nauk [Doklady Earth Sciences], vol. 456, no. 4, pp. 443-447. (In Russ.) https://doi.org/10.7868/S0869565214160191 


\title{
Петрохимические особенности дайкового комплекса Воронцовского золоторудного месторождения (Северный Урал)
}

\author{
Оксана Борисовна АЗОВСКОВА", \\ Михаил Юрьевич РОВНУШКИН", \\ Елена Индустровна СОРОКА"
}

\section{Институт геологии и геохимии им. А. Н. Заварицкого УрО РАН, Екатеринбург, Россия}

\begin{abstract}
Актуальность работы. Воронцовское месторожцение обладает характерными чертами "карлинского" типа и является одним из самых крупных золоторудных месторожцений Урала, однако в настояшее время оно практически выработано, а объекты-аналоги в регионе не выявлены. Аайковый комплекс штокверкового типа ранее на месторождении не изучался. Проводимые исследования могут способствовать уточнению как модели формирования оруденения, так и прогнозно-поисковой модели.

Цель работы. Изучение состава и петрохимических особенностей дайкового комплекса Воронцовского месторожцения как одного из возможных факторов формирования золотого оруценения.

Методы исследований. Проведены замеры элементов залегания даек в пределах действующего карьера с вынесением результатов на азимутальную сетку. Выполнен силикатный анаииз образцов даек, использованы также имеюшиеся Аанные прошлых лет. Петрограсическое изучение Ааек сопровожАалось исследованием образцов при помоши сканируюшего электронного микроскопа JSM-6390LV (JEOL) с ЭАC-cпектрометром IncaEnergy 450 и электронно-зондового микроанализатора Cameca SX100.

Результаты работы. На первом этапе исследований уточнена структурная позиция Ааек, проведено обобщение результатов петрограсических, петрохимических работ и Аанных, полученных на микроанализаторах. Установлено значительное преобладание основных Ааек при вариациях составов от пикробазальта Ао габбродиорита (андезибазальта). Выявлена группа даек с повышенной и высокой щелочностью (в том числе лампрофиры) с составами от умеренно-шелочного и щелочного пикробазаяьта Ао монцодиорита (трахиандезибазальта). В Аайках нормального ряда засиксированы проявления камишпатового метасоматоза с минерамьной ассоциацией хлорит-кварц-КПШ-пирит ( \pm галенит). Ранее участки калишпатизации наблюдаяись во вмещаюших тусооалевролитах.

Выводы. Наличие Аайкового штокверка можно рассматривать как положительный структурный фактор в образовании месторожхения. Его роль как магматического фактора неясна, однако можно предположить, что проявления камишпатизации генетически связаны с Аайками повышенной шелочности.
\end{abstract}

Киючевые слова: Северный Урал, Воронцовское золоторудное месторожцение, Аайки, петрохимия, камишпатовый метасоматоз, карлинский тип.

Работа выполнена в рамках темы государственного задания ИГГ УрО РАН (гос. регистрации №ААААA18-118052590030-2).

\section{ЛИТЕРАТУРА}

1. Сазонов В. Н., Мурзин В. В., Григорьев Н. А. Воронцовское золоторудное месторождение - пример минерализации карлинского типа на Урале // Геология рудных месторождений. 1998. Т. 40, № 2. С. 157-170.

2. Murzin V. V., Naumov E. A., Azovskova O. B., Varlamov D. A., Rovnushkin M. Yu., Pirajno F. The Vorontsovskoe Au-Hg-As ore deposit (Northern Urals, Russia): Geological setting, ore mineralogy, geochemistry, geochronology and genetic model // Ore Geology Reviews. 2017. Vol. 85. P. 271-298. https://dx.doi.org/10.1016/j.oregeorev.2016.10.037

3. Викентьев И. В., Тюкова Е. Э., Мурзин В. В. и др. Воронцовское золоторудное месторождение. Геология, формы золота, генезис. Екатеринбург: Форт Диалог-Исеть, 2016. 206 с.

4. Сазонов В. Н., Мурзин В. В., Григорьев Н. А., Гладковский Б. А. Эндогенное оруденение девонского андезитоидного вулкано-плутонического комплекса (Урал). Свердловск: УрО АН СССР, 1991. 184 с.

5. Нечкин Г. С., Ровнушкин М. Ю. Сульфидная околодайковая минерализация на Воронцовском месторождении золота (Ауэрбаховский комплекс, Северный Урал) // Ежегодник-2010: труды ИГГ УрО РАН. 2011. Вып. 158. С. 187-190.

6. Ровнушкин М. Ю., Гуляева Т. Я., Галахова О. Л. Проявление калишпатового метасоматоза в пределах Воронцовского золоторудного месторождения // Ежегодник-2009: труды ИГГ УрО РАН. 2010. Вып. 157. С. 241-244.

7. Cline J. S., Hofstra F. F. Ore-fluid evolution at the Getchell Carlin-type gold deposit, Nevada, USA // European Journal of Mineralogy. 2000. Vol. 12, № 1. P. 195-212. https://dx.doi.org/10.1127/ejm/12/1/0195

8. Cline J. S., Hofstra F. F., Muntean J. L. et al. Carlin-type gold deposits in Nevada: critical geologic characteristics and viable models // Economic Geology. 2005. 100 th Anniversary Volume, № 3. P. 451-484. URL: https://pyrite.utah.edu/fieldtrips/SEGFnevada2007/Readings/General_CTD/ Cline2005.pdf

9. Ressel M. W., Henry C. D. Igneous geology of the Carlin Trend, Nevada: development of the eocene plutonic complex and significance for Carlin-type gold deposits // Economic Geology. 2006. Vol. 101, № 2. P. 347-383. https://dx.doi.org/10.2113/gsecongeo.101.2.347

10. Almeida C. M., Olivo G. R., Chouinard A., Weakly Ch., Poirier G. Mineral Paragenesis, alteration, and geochemistry of the two types of gold ore and the host rocks from the Carlin-type deposits in the southern part of the Goldstrike Property, Northern Nevada: implications for sources of ore-forming elements, ore genesis, and mineral exploration // Economic Geology. 2010. Vol. 105, № 5. P. 971-1004. https://doi.org/10.2113/ econgeo.105.5.971

11. Liu J., Dai H., Zhai D., Wang J., Wang Y., Yang L., Mao G. et al. Geological and geochemical characteristics and formation mechanism of the Zhaishang Carlin-like type gold deposit, western Qinling Mountains, China // Ore Geology Reviews. 2015. Vol. 64. P. 273-298. https://doi. org/10.1016/j.oregeorev.2014.07.016

12. Wang L., Zhu Y. Multi-stage pyrite and hydrothermal mineral assemblage of the Hatugold district (west Junggar, Xinjiang, NW China): Implications for metallogenic evolution // Ore Geology Reviews. 2015. Vol. 69. P. 243-267. https://dx.doi.org/10.1016/j.oregeorev.2015.02.021

oazovskova@yandex.ru

http://orcid.org/0000-0003-4251-7414

rovn@list.ru

https://orcid.org/0000-0003-1759-2818

soroka@igg.uran.ru

iD http://orcid.org/0000-0003-1360-6274

26 Азовскова О.Б. и др. Petrochemical features of the dike complex of the Vorontsovskoye gold-ore deposit (Northern Urals) // Известия УГГУ. 2019. Вып. 1(53). C. 18-27. DOI 10.21440/2307-2091-2019-1-18-27 
13. Zhu J.-J., Hu R.-Zh., Richards J. P., Bi X.-W., Stern R., Lu G. No genetic link between Late Cretaceous felsic dikes and Carlin-type Au deposits in the Youjiang basin, Southwest China // Ore Geology Reviews. 2017. Vol. 84. P. 328-337. https://dx.doi.org/10.1016/j.oregeorev.2017.01.014

14. Минина О. В. Ауэрбаховская комплексная рудно-магматическая система на Среднем Урале // Отечественная геология. 1994. № 7. С. 17-23.

15. Грабежев А. И., Ронкин Ю. Л., Пучков В. Н., Гердес А., Ровнушкин М. Ю. Краснотурьинское медно-скарновое рудное поле (Северный Урал): U-Pb возраст рудоконтролирующих диоритов и их место в схеме металлогении региона // ДАН. 2014. Т. 456, № 4. С. $443-447$.

Статья поступила в редакцию 18 декабря 2018 г. 